\title{
Lembaga Perdamaian Sebagai Alternatif $: \cdots$ Penyelesaian Sengketa Dalam Pandangan Peradilan Islam Dan Hukum Positif.
}

\author{
Abdul Jamil
}

Abstrak
In Islam to settle dispute peacefully or reconciliation is acceptable, even it is recommended
as far as relates to the rights of the people based onjustice. In order the decision of
reconciliation has a legal effect to the parties, it is necessarily to request the court to
strengthen the reconciliation to be the court decision. In addition, if in the future, one of the
parties does not obey the reconciliation, the reconciliation can be forced by the court to be
executed.

\section{Pendahuluan}

Lembaga Perdamaian merupakan istilah yang tidak asing bagi ummat Islam. Dalam Islam, Lembaga Perdamaian ini dikenal dengan istilah "Hakam" yang diambil dari semangat firman Allah SWT. dalam surat An-Nisa' ayat (35). Sebagaimana sang Khaliq telah memberikan petunjuk dan bimbingan bagi manusia ketika mempunyai kasus atau terjadi persoalan dalam rumah tangga yang menyebabkan cekcok terus menerus (syiqaq) maka yang bersangkutan dianjurkan membentuk lembaga mediasi yang disebut Hakam.
Meskipun dalam ayat tersebut khusus mengenai syiqaq, akan tetapi secara umum dapat difahami juga suatu kasus umum yang biasa terjadi dalam rumah tangga atau dalam pergaulan yang lain. Apabila ada dua orang atau lebih mempunyai masalah, maka dapat mengangkat "Hakam" (juru damai) sedangkan lembaganya disebut tahkim ${ }^{1}$ dan orang yang mendamaikan disebut muhakkam yang mempunyai. tujuan mulia yaitu "Islah" (mendamaikan) di antara orang yang mempunyai masalah tersebut.

Perintah tentang mendamaikan orang yang sedang berperkara (sengketa) merupakan ajaran

1 Tahkim menurut pengertian bahasa adalah menyerahkan putusan pada seseorang dan menerima utusan itu, sedangkan menurut istilah adalah dua orang atau lebih mentahkimkan kepada seseorang diantara mereka untuk diselesaikan sengketa dan diterapkan hukum sara' atas sengketa mereka itu. T.M. Hasbi Ashshidieqy, Peradilan dan Acara Islam, (Bandung: al-Ma'arif. Tanpa tahun), hlm. 69. 
Islam yang mulia, sebagaimana firman Allah SWT. dalam surat Al-Hujarat ayat (9). Dalam ayat ini Allah' SWT. memberikan petunjuk kepada orang yang beriman apabila ada dua orang yang berperang (bertengkar) maka damaikanlah antara mereka dengan adil. Karena Allah SWT menyukai orang-orang yang berlaku adil.?

Apabila kita merujuk pada surat An-Nisa' ayat (35) dan al-Hujarat ayat (9) di atas, manakala kita mempunyai kasus khususnya perkawinan atau perkara pada umumnya, Allah SWT memerintahkan untuk membentuk hakam (juru damai) atau tahkim (lembaga mediasi) sebagai langkah alternatif penyelesaian masalah. Penyelesaian yang dimaksud adalah untuk perdamaian.

Tuntunan Allah SWT. yang diberikan kepada manusia ketika mereka mempunyaai masalah untuk berdamai tersebut amatlah indah. Sebab kalau manusia itu mau berdamai dalam menghadapi masalah, tentu saja tidak akan timbul pertikaian di muka bumi ini. Sehingga kehidupan manusia menjadi tenteram dan damai karena tidak ada dendam (kusumat) di antara mereka. Tidak ada lagi orang yang merasa didlolimi dan dipermalu-kan sehingga berjuang secara membabibuta untuk mempertahankan harga dirinya. Misalnya seorang yang diperkarakan di Pengadilan merasa harga dirinya diserang sehingga dia harus mempertahankan. Bahkan tidak jarang cara yang digunakan itu dengan menempuh jalan-jalan yang bertentangan dengan hukum atau setidak-tidaknya melanggar hukum dan etika. Misalnya, praktik suap atau jalur-jalur di luar hukum, dalam bahasa hukum acara disebut dengan istilah eigenrichting atau main hakim sendiri, ${ }^{3}$ untuk merebut kemenangan tidak peduli apakah cara yang ditempuh benar atau salah.

Konsep penyelesaian sengketa atau masalah hak yang diajarkan Isiam tersebut, memberikan inspirasi terhadap substansi dan prosedur penyelesaian sengketa sebagaimana diatur dalam Undang-Undang No. 14 Tahun 1970 jo Undang-Undang Nomor 35 tahun 1999 jo Undang-Undang No. 4 tahun 2004 (tentang Ketentuan Pokok Kekuasaan Kehakiman, serta undang-undang organik lainnya. Di Pengadilan Agama undang-undang organik sebagai dasar sumber hukum acaranya ada Undang-Undang No. 1 Tahun 1974, PP No. 9 Tahun 1975. Selain itu juga terdapat UndangUndang No. 7 Tahun 1989 tentang Peradilan Agama, mewajibkan kepada para hakim untuk mendamaikan para pihak yang berperkara di pengadilan. Undang-undang tersebut juga memberdayakan ketentuan Pasal $130 \mathrm{HIR} /$ $154 \mathrm{RBg}$. sebagai pedoman dalam beracara di pengadilan yang mengatur juga tentang perdamaian.

Semangat perdamaian yang tercantum dalam undang-undang tersebut mendorong Mahkamah Agung Republik Indonesia (MARI) mengeluarkan Peraturan Mahkamah Agung (PERMA) No. 2 Tahun 2003 tentang Prosedur Mediasi di Pengadilan. Dasar pertimbangan dikeluarkannya PERMA, bahwa pengadilan sebagai lembaga yang dipergunakan untuk

${ }^{2}$ Abdul Manan, Penerapan Hukum Acara Perdata di Lingkungan Peradilan Agama, Cetakan. Pertama, (Jakarta: Al-Hikmah, 2000), him. 95

3Sudikno Mertokusumo, Hukum Acara Perdata di Indonesia, Edisi kelima Cetakan Kedua, (Yogyakarta: Liberty, 1999), hlm. 2 
menyelesaikan perkara dan untuk mengatasi penumpukan perkara di pengadilan. Selain itu, MARI juga menyadari bahwa proses mediasi merupakan salah satu proses penyelesaian perkara yang lebih cepat dan murah, serta dapat memberikan akses kepada para pihak yang bersengketa untuk memperoleh keadilan atau penyelesaian yang memuaskan atas sengketa yang dihadapi.

\section{Tahkim dalam sejarah Peradilan di Indonesia}

Apabila ditelusuri sejarah berdirinya pengadilan di Indonesia, khususnya Pengadilan Agama tidak lepas dari penyebaran agama Islam pada waktuitu. Proses penyadaran dalam agama Islam diikuti dengan proses penyadaran terhadap hukum-hukum Islam. Misalnya konsekuensi perkawinan melahirkan keturunan yang kemudian timbul kewarisan, kemudian berkembanilah hukum-hukum yang lain. Ketika di antara umat Islam mempunyai masalah, misalnya perkawinan, kewarisan atau yang lain maka diterapkan hukum Islam sebagai dasar untuk menyelesaikan persoalan mereka itu.

Para mubalig penyebar agama Islam itulah yang menyadarkan mereka terhadap hukum Islam, maka ketika mereka mempunyai masalah yang harus dihukumi misalnya perkawinan, kewarisan, masalah harta dan sebagainya, mereka membutuhkan tempat untuk menyelesaikannya. Oleh karena tempat itu belum ada tentu saja mereka membutuhkan orang yang dianggap memiliki pengetahuan dan integritas di bidang hukum Islam untuk menyelesaikan masalahnya. Pada waktu itu orang yang dianggap mempunyai ilmu tentang hukum Islam adalah mubalig, dan kemudian kepada dialah mereka menyelesaikan perselisihan yang timbul di antara mereka. Masalah yang diselesaikan oleh mubalig itu tidak saja terbatas pada perkara perdata saja, tetapi juga perkara-perkara pidana. Misalnya pencurian, perzinahan dan lain sebagainya. Cara menyelesaikan masalah seperti itu dikenal dengan istilah "tahkim" yaitu menyerahkan persoalan yang perlu dihukumi antara orang yang mempunyai masalah kepada orang yang mempunyai ilmu tentang hukum agama dan dianggap mempunyai kemampuan untuk menyelesaikan perkara dengan melaksanakan prinsip peradilan. ${ }^{4}$ Tahkim inilah kemudian lama kelamaan melembaga di tengah-tengah masyarakat Islam.

Keberadaan lembaga tahkim di tengahtengah masyarakat sangat ditunggu-tunggu, hal ini disebabkan fungsinya yang dapat memecahkan serta menyelesaikan persoalan yang mereka hadapi, karena lembaga peradilan ketika itu belum ada sedangkan masyarakat membutuhkan perlindungan untuk menjamin hak-haknya apabila ada pelanggaran terhadap hak seseorang. Kebutuhan terhadap sebuah peradilan itu sifatnya manusiawi, oleh karena peradilan dianggap dapat melindungi kepentingan manusia untuk hidup damai tenteram dan manusia tidak mungkin menghindari persengketaan. Lembaga peradilan merupakan lembaga yang berfunǵsi untuk menegakkan, memerintahkan kebaikan dan mencegah bahaya kedlaliman, menyampaikan hak kepada yang punya, mencegah tindakan kedlaliman, mengusahakan islah di antara manusia. ${ }^{5}$

${ }^{4}$ Daniel S. Lev. Peradilan Agama Islam di Indonesia alih bahasa Zaini Ahmad Noeh, Cetakan. Kedua, (Jakarta: Intermasa, 1986), hlm. 2. Baca juga T.M. Hasbi Ashshidiqi, Op. Cit, hlm. 69 
Oleh karena pada masa itu peradilan belum ada maka tahkim menjadi pilihan tempat orang menyelesaikan masalahnya. Lembaga tahkim lama kelamaan dapat diterima dan dijalankan oleh kelompok masyarakat Islam yang mampu menjalankan tata kehidupan melalui penguasa yang waktu itu adalah raja-raja Islam, ${ }^{6}$ akhimya tahkim tersebut dikembangkan dalam bentuk peradilan dengan nama yang berbeda-beda. $\mathrm{Di}$ Jawa disebut dengan "Pengadilan Serambi" karena sidang-sidangnya dilakukan di serambiserambi masjid, Pengadilan Darigama dan Pengadilan Cilaga. Di Paiembang disebut pengadilan agama disamping Pengadilan Syahbadar dan Pengadilan Patih, di sebagian Kalimanatan Selatan dan Timur "Kerapatan Qadi" dan "Kerapatan Qadi Besar" dan 'Mahkamah Syar'ah".

Perkembangan lembaga tahkim menjadi sebuah pengadilan adalah tuntutan yang wajar karena perkembangan manusia yang mengikuti perkembangan budaya manusia. Di samping itu bentuk pelembagaan semacam itu tumbuh dan berkembang sesuai dengan perkembangan masyarakat itu sendiri. Luasnya hubungan manusia yang tidak dapat dibatasi oleh ruang dan waktu diiriünigkinkăı banyak menimbulkan persoalan yang menyangkut kehidupan manusia. Timbulnya persoalan tentu saja berdampak pada perlunya adanya aturan (hukum) untuk mengatur dan melindungi hak manusia.

Hukum Islam (dalam al-Qur'an, al-Hadits dan kitab-kitab fiqih sebagai hasil ijtihad) yang dikembangkan para mubalig dan yang sudah dijalankan oleh umat Islam itu tidaklah hanya untuk sekedar dibaca, dilihat atau diketahui saja, akan tetapi sebagai pedoman untuk tata kehidupan menusia yang harus dilaksanakan dan ditaati. ${ }^{8}$

Kalau sudah ada hukum sebagai aturan dalam kehidupan manusia tentu saja tidak boleh dilanggar, apabila ada pelanggaran dan untuk mempertahankan berlangsungnya hukum tersebut, maka perlu adanya alat untuk menegakkannya. Apabila mengacu pada pemahaman hukum perdata Barat, peraturan atau hukum yang mengatur tentang ditaatinya aturan-aturan atau ketentuan hukum (hukum materiil) itu disebut dengan hukum acara perdata atau hukum formil. ${ }^{9}$

Pada awal masa pertumbuhan hukum Islam di Indonesia, gagasan pembentukan peradilan itu menjadi penting. Karena pengadilan dianggap sebagai bagian dari pranata hukum untuk memeṇuhi kebutuhan penegakan hukum dan keadilan yang mengacu pada hukum yang berlaku. ${ }^{10}$ Maka tidak heran peradilan serambi, kerapatan qadi dan kerapatan qadi besar serta mahkamah syariah dan sebagainya, disambut

\footnotetext{
${ }^{5}$ Muhammad Salam Madkur, Peradilan Dalam Islam, Alih bahasa Imran AM.,Cetakan Keempat, (Surabaya: Bina llmu, 1990), hlm. 31.

${ }^{6}$ Daniel S. Lev. Op.cit., hlm. 2,3

${ }^{7}$ Cik Hasan Bisri, Peradilan Islam Dalam Tatanan Masyarakat Indonesia, Cetakan Pertama, (Bandung: Remaja Rodakarya, 1997), hlm. 96 - 97. Lihat juga Daniel S. Lev., Peradilan Agama Islam di Indonesia, Alih Bahasa Zaini Ahmad Noeh, Cetakan Kedua, Jakarta, Intermasa, 1986, hlm. 25 - 27. Muhammad Daud Ali, Hukum Islam dan Peradilan Agama (Kumpulan Tulisan), Ed.1, Cetakan. 1, (Jakarta: Raja Grafindo Persada, 1997), hlm. 224-225.

${ }^{8}$ Bandingkan pendapat Sudikno Mertokusumo, Op.Cit., hlm. 1

${ }^{9}$ bid., him. 2

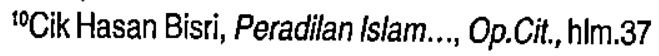


baik oleh masyarakat Islam bahkan diterima sebagai tempat untuk mencari keadilan manakala terjadi pelanggaran hak (sengketa).

Setelah masuknya Pemerintah Hindia Belanda dikembangkanlah peradilan yang menganut sistem hukum Barat secara melembaga seiring dengan dikembangkannya sistem hukum Barat di Indonesia. Untuk mence-gah perlawanan dari ummat Islam karena hukum anak negeri dan agama Islam dilanggar, maka pada tahun 1882 di Jawa dan Madura didirikan peradilan agama dengan nama priesterraad atau raad agama menjadi peradilan yang sah secara legal diakui oleh pemerintah Hidia Belanda." Sejak melembaganya peradilan Agama di Jawa dan Madura seperti Landraad (Pengadilan Negeri) peran lembaga tahkim tidak ada, karena apabila ada persoalan dalam perkara keperdataan mereka menggunakan pengadilan agama bagi mereka yang beragama Islam dan apabila perkara itu menyangkut pidana ditangani oleh Landraad (Pengadilan Negeri).

\section{Hukum Mentahkimkan Perkara dalam Islam}

Maksud hukum dalam tulisan ini adalah merujuk pada lima kaidah hukum Isiam yang disebut al-ahkam al-khamsah yang terdiri dari mubah atau boleh, sunnah, wajib, makruh dan haram. Sedangkan yang dimaksud dengan mentahkimkan perkara adalah menyelesaikan perkara atau sengketa yang dihadapi oleh orang yang berperkara kepada seorang hakam (juru damai).

Hukum Islam pada prinsipnya mengatur perikehidupan manusia itu pada dua dimensi yang dikenal dengan hubungan vertikal dan horizontal. Hubungan vertikal yaitu hubungan manusia dengan Allah SWT., sedangkan hubungan horizontal adalah hubungan manusia dengan manusia lain, manusia dengan benda dan alam lingkungan hidupnya. ${ }^{12}$ Hubungan manusia dengan Allah diatur dalam ibadah, sedang hubungan manusia dengan sesama manusia dan alam lingkungan sekitarnya diatur dalam bidang muamalah, dalam arti luas baik yang bersifat perorangan maupun umum. ${ }^{13}$

Hukum Islam mengatur mengenai semua bidang tersebut di atas, dan karena dalam kehidupan manusia di dunia ini tidak dapat dilepaskan dengan kehidupan diakhirat kelak. Artinya kehidupan manusia di akhirat ditentukan oleh perbuatan kehidupan di dunia. Oleh karena itu, meskipun muamalah mengatur pergaulan hidup duniawi tetapi nilai-nilai amal tidak dapat dipisahkan. Sedangkan nilainilai agama yang melekat dalam bidang muamalat adalah hukum halal dan haram. ${ }^{14}$ Halal artinya perbuatan itu dibenarkan atau dibolehkan dalam Islam. Sedangkan haram perbuatan itu dilarang dalam Islam sehingga bagi orang yang mengerjakan larangan itu mendapatkan dosa atau siksa besok di akhirat.

11Mohammad Daud Ali, Hukum Islam Dan Peradilan Agama (Kumpulan Tulisan), Ed. 1, Cetakan 1, Jakarta, Raja Grafindo Persada, 1997, hlm. 26. Baca juga Hadari Djenawi Taher, Undang-Undang Peradilan Agama Beserta Pokok-Pokok Pikiran dalam UU Peradilan Agama, (Jakarta: Alda, 1989), hlm. 3.

${ }^{12 M u h a m m a d}$ Daud Ali dan Habibah Daud, Lembaga-lembaga Islam di Indonesia, Ed. 1, Cetakan. 1, (Jakarta: Raja Grafindo Persada, 1995), hlm. 28

${ }^{13}$ Ahmad Azhar Basjir, Asas-asas Hukum Muamalat, Ed. Revisi. (Yogyakarta: Ull Pres, 2000), hlm. $6-7$

${ }^{14} \mathrm{lbid}$., him. 13 
Merujuk pada penjelasan tersebut di atas, mentahkim perkara dalam pandangan Islam memang tidak diharamkan (tidak dilarang) yang berarti dibolehkan. Hal ini dapat diambil dari al-Qur'an surat an-Nisa' ayat (35) dan alHujarat ayat (9). Dalam kedua surat tersebut Allah SWT. justru memberikan petunjuk kepada manusia apabila mempunyai sengketa diselesaikan dengan cara damai (islah). Bahkan dalam hadits Nabi yang diriwayatkan oleh an-Nasa'i membolehkan tahkim tersebut. ${ }^{15}$

Dibolehkannya orang yang mempunyai sengketa menyelesaikan melalui tahkim dalam pandangan Islam dapat diterima oleh akal sehat. Karena pada prinsipnya sengketa itu berkaitan dengan hak. Apabila dilihat dari katgori pembagian hak dalam hukum Islam dibagi menjadi tiga. Yaitu : (1) Hak Allah (2) Hak manusia dan (3) Hak gabungan antara hak Allah dan hak Manusia. ${ }^{16}$

Pengertian hak Allah sebagaimana pendapat Imam Al-Qarafi ulama terkemuka dalam Madzhab Maliki sebagaimana dikutip oleh Ahmad Azhar Basjir; adalah perintah dan larangan-larangannya. Segala ketentuan Allah yang tidak darant digunakan oleh manusia, seperti larangan zina, larangan riba, perintah salat dan sebagainya, yang semua dimaksudkan untuk menegakkan kebaikan dalam hidup manusia. Sedangkan hak manusia adalah segala hal yang berhubungan dengan kepentingan perorangan yang tidak secara: langsung. menyangkut kepentingan masyarakat. Hak manusia ini tidak dapat digugurkan kecuali oleh manusia itu sendiri. Hak gabungan adalah yang secara bersamaan antara hak Allah dan manusia. ${ }^{17}$

Apabila dilihat dari tiga kategori tersebut yang dihubungkan dengan pengguguran hak, maka sengketa yang ditahkimkan itu menyangkut hak manusia tentu saja menjadi wewenang manusia itu sendiri. Sehingga pihak yang bersengketa atas pelanggaran hak manusia, maka pihak yang mempunyai hak yang dilanggar itu diberi kebebasan, mau meminta bantuan hakam (juru damai) atau dia meminta bantuan negara, atau bahkan dia mengikhlaskannya (menggugurkan kewajiban pelanggar hak) tersebut.

Pada intinya pengguguran hak manusia adalah hak manusia itu sendiri karena bukan hak Allah dan hak gabungan, sehingga manusia itu sendiri yang menyelesaikan. Hal ini berbeda dengan pelanggaran terhadap hak gabungan (antara hak Allah hak manusia) maka tergantung hak mana yang lebih dominan. Kalau hak Allah yang dominan maka untuk melindungi manusia dan tatanan masyarakat secara umum tentu hak Allah yang ditonjolkan. Akan tetapi kalau hak manusia yang lebih dominan maka hak manusia yang ditonjolkan. ${ }^{18}$

Berkaitan dengan pengguguran hak dan hukum mentahkimkan perkara tersebut di atas dapat diambil suatu pemahaman perkara yang diperbolehkan untuk diselesaikan melalui jalan tahkim adalah perkara perdata, kecuali talak. Sebab perkara perdata itu merupakan kategori hak manusia, sedangkan talak meskipun hak manusia akan tetapi demi kemaslahatan penggunaannya dibatasi dan harus ada izin negara melalui pengadilan.

\footnotetext{
${ }^{15}$ T.M. Hasbi Ash-Shiddieqy, Op. Cit., hlm. 70

${ }^{16}$ Ahmad Azhar Basjir, Op.Cit., hlm. 20-22

${ }^{17} \mathrm{lbid}$, hlm. 21-23

${ }^{18} \mathrm{Ibid}$., hlm. 23
} 
Dalam perkara pidana meskipun sebagian besar pendapat ulama' tidak diperbolehkan, karena kewenangan pengguguran hak itu hanya Allah SWT. dan hanya penguasa saja yang dapat memutuskan. ${ }^{19}$ Tetapi menurut penulis tidak setiap perkara pidana, sebab dalam perkara pidana itu terdapat dua hak secara bersamaan, yaitu hak Allah dan hak manusia dan penerapan hukumannya tergantung mana yang ditonjolkan. Apakah hak Allah atau hak manusia. Oleh karena itu terhadap perkara pidana tergantung hak mana yang ditonjolkan. Apabila yang ditonjolkan hak manusia maka bisa saja didamaikan. Karena yang didamaikan haknya manusia sedangkan hak Allah tetap menjadi kewenangan negara (pengadilan). Sebagai contoh, membunuh dengan sengaja atau menganiaya dengan sengaja. Dalam kasus ini ada dua hak yang timbul secara bersamaan, yaitu hak Allah yaitu qishas dan hak manusia karena menjadi korban. Qishas dapat dijalankan, akan tetapi apabila si pelaku dimaafkan oleh korban atau keluarga korban yang mengalami penderitaan, maka qishas tidak diterapkan 'dan diganti dengan diyat berupa pembayaran sejumlah harta oleh pelaku, sebab akibat dari pembunuhan atau penganiayaan itu langsung dirasakan oleh keluarga terbunuh (korban) atau korban penganiayaan itu. ${ }^{20} \mathrm{Hal}$ ini berbeda dengan qishas tuduhan zina. Karena tuduhan zina itu yang dominan adalah hak Allah, yaitu Allah melindungi masyarakat agar jangan mudah menuduh orang dengan mencemarkan nama baik orang, maka pelaku tidak dapat dimaafkan oleh korban dan yang diterapkan adalah qishasnya (hukumannya).

\footnotetext{
${ }^{19}$ T.M. Hasbi Ash-Shiddieqy, Op. Cit., hlm. 71

20 Ahmad Azhar Basyir, Loc. Cit.
}

\section{Fungsi Tahkim}

Sebagaimana diuraikan di bagian awal tulisan ini, bahwa tahkim dijadikan' oleh masyarakat sebagai lembaga untuk menyelesaikan sengketa di antara mereka dengan jalan perdamaian (islah), melalui jalan damai inilah proses penyelesaian sengketa menjadi cepat karena prosedur yang ditempuh sederhana dan tidak birokratis.

Penyelesaian melalui tahkim apabila dilihat dari dasar hukumnya Qur'an surat anNisa' ayat (35) dan al-Hujarat ayat (9) adalah penyelesaian dengan jalan damai (islah). Sehingga muhakkam harus berfungsi sebagai juru damai. Pedoman sebagai muhakkam memang tidak ada prosedur tetapnya sebagai pedoman beracara seperti dalam proses sidang di Pengadilan. Tetapi rambu-rambu yang diberikan Allah SWt. dalam surat alHujarat (9) adalah hanya menyebutkan melalui dengan cara yang adil.

Dalam melaksanakan fungsi tahkim untuk mendamaikan dengan adil tersebut maka muhakkam mempunyai tugas menyadarkan kepada kedua belah pihak yang bersengketa bahwa penyelesaian dengan cara damai mempunyai tujuan agar kedua belah pihak tidak timbul kusumat, dengki, dendam dan segala sifat-sifat yang tidak baik lainnya. Sehingga pihak yang bersengketa mau mengalah satu dengan yang lainnya, karena menyelesaikan sengketa melalui jalur tahkim ini tidak ada yang menang dan tidak ada yang kalah, sehingga para pihak dengan hati yang puas (legowo) tidak akan mempersoalkan putusan yang telah putuskan. 
Perlu disadari pekerjaan Muhakkam semacam itu berat, karena keputusan yang diambil oleh muhakkam harus bisa diterima oleh kedua belah pihak yang bersengketa, itulah yang dimaksud adil dan putusannya harus mengakhiri sengketa. Untuk melaksanakan fungsi tersebut maka muhakkam perlu melaksanakan prinsip peradilan, yaitu (1) mendudukkan kedua belah pihak yang bersengketa dalam posisi yang seimbang, artinya tidak ada yang mempunyai posisi lebih dari yang lain (2) mendengarkan argumentasi dari pihak yang bersengketa, bahkan kalau perlu mendengarkan saksi bahkan ikrar (pengakuan), karena muhakkam dibolehkan memutuskan berdasarkan ikrar; karena semua itu adalah hukum yang sesuai dengan syara'.21 (3) menyadarkan kepada para pihak agar mau melaksanakan isi putusan yang diputuskan oleh muhakkam. Hal ini penting karena putusan tahkim berbeda dengan keputusan pengadilan, meskipun proses tahkim hampir sama dengan pengadilan.

Putusan tahkim hanya berlaku bagi orangorang yang menerima putusannya, sedangkan putuşan pengadilan harus berlaku meskipun tidak diterima oleh orang-orang yang bersangkutan, ${ }^{22}$ bahkan putusan pengadilan bisa diterapkan pada orang lain dalam kasus yang sama (dijadikan sebagai yurisprudensi). Putusan tahkim tidak dapat dipaksakan oleh lembaga yang memutuskan (tahkim) manakala pihak itu tidak mau patuh terhadap putusan, sedangkan putusan pengadilan dapat dipaksakan oleh lembaga yang mernutuskan (pengadilan) kepada pihak yang tidak mau menerima putusan tersebut.

\footnotetext{
${ }^{21}$ T.M.Habsy Ash-Shiddieqy, Op.Cit., hlm. 72

${ }^{22}$ lbid., hlm. 69
}

Perbedaan terhadap putusan tersebut dapat diterima oleh akal sehat, karena ada hal yang berbeda antara tahkim dan pengadilan. Lembaga tahkim meskipun melaksanakan prinsip peradilan dalam memutus dan menyelesaikan sengketa, tetapi penekanannya berbeda. Tahkim lebih menekankan pada aspek perdamaiannya bukan pada menang kalah atau salah benar, sehingga orang yang meminta diputuskan oleh lembaga tahkim tersebut tidak ada yang merasa ada yang kalah dan menang. Dampak terhadap putusan tahkim orang dengan sukarela melaksanakan isi putusan, karena (1) pihak yang datang ke pada tahkim iłu dengan kesadaran bahwa muhakam dianggap orang yang tahu agama dapat dipercaya memutuskan berdasarkan nilai-nilai keadilan yang ada pada agama, (2) pihak yang bersengketa tidak merasa dikalahkan. Sebab pendekatan yang digunakan oleh lembaga tahkim dalam menyelesaikan sengketa tidak kalah menang atau salah benar tetapi pendekatan win-win solution.

Berbeda dengan putusan pengadilan yang berisi menang dan kalah, sehingga pendekatan yang digunakan oleh hakim dalam memberikan putusan adalah salah dan benar. Pendekatan ini menyebabkan persepsi bahwa pihak yang dikalahkan di pengadilan itu pasti orang yang bersalah.

Secara psikologis putusan pengadilan semacam itu berdampak kepada orang yang berperkara, yaitu pihak yang dinyatakan kalah adalah orang yang bersalah. Padahal dalam praktik, orang yang dikalahkan dalam putusan pengadilan belum tentu bersalah. Bisa saja karena kepandaian untuk memberikan 
argumentasi, formalistik hukum atau karena sebab yang lain. Sehingga pihak yang tidak dapat memberikan argumen dengan baik, atau pihak yang mempunyai kelemahan formalistik aturan hukum atau pihak yang tidak mau atau setidak-tidaknya tidak pandai untuk berbuat yang bertentangan dengan hukum atau etika atau setidak-tidaknya tidak bisa berbuat sesuatu. yang dianggap di luar kemampuan manusia, maka dia dinyatakan kalah.

Pihak yang kalah karena sebab-sebab tersebut kemudian dirugikan dengan putusan pengadilan karena dikalahkan, maka biasanya pihak yang dikalahkan tersebut tidak dapat menerima pütusan pengadilan secara lapang dada bahkan tidak jarang menimbulkan kedengkian dan dendam di antara mereka yang terlibat dalam proses peradilan.

\section{Tahkim dalam pandangan PERMA NO. 2 Tahun 2003}

Dari penjelasan di atas, tahkim dan mentahkimkan sengketa melalui lembaga tahkim dalam pandangan agama Islam dibolehkan bahkan dianjurkan. Agar hasil putusan tahkim itu bermakna bagi pihak yang mentahkimkan sengketanya, maka perlu diselaraskan dengan PERMA No. 2 Tahun 2003.

Sebagaimana diketahui, salah satu pertimbangan yang melatar belakangi terbitnya Perma tersebut adalah mediasi merupakan salah satu proses lebih cepat dan murah, serta dapat memberikan akses kepada para pihak yang bersengketa untuk memperoleh keadilan atau penyelesaian yang memuaskan atas sengketa yang dihadapi. Atas dasar pertimbangan tersebut, maka dapat dipahami bahwa mediasi mempunyai tujuan untuk mempercepat penyelesaian sengketa yang diajukan ke pengadilan. Di samping itu, penyelesaian dengan jalan perdamaian berdampak pada perkara menjadi sederhana cepat dan biaya murah.

Apabila-dicermati pertimbangan Perma No. 2 Tahun 2003 tersebut pada prinsipnya sama dengan tujuan dalam tahkim, dalam sistem peradilan Islam, yaitu menyelesaikan perkara secara damai yang didasarkan pada keadilan, oleh karena itu perlu memadukan antara tahkim dengan hukum acara yang beriaku di pengadilan. Langkah itu perlu diambil karena adanya perbedaan antara putusan lembaga tahkim dengan pengadilan.

Sebagaimana dijelaskan di atas; bahwa perbedaan antara putusan tahkim dengan putusan pengadilan terletak pada kekuatan mengikatnya suatu putusan terhadap pihak yang bersengtketa. Apabila dilihat dari segi teknis, putusan tahkim dapat memenuhi syarat formal perdamaian dalam hukum acara perdata. Meskipun dajam hukum acara perdata tidak mensyaratkan bentuk formal hasil perdamaian, yang penting para pihak setuju dan sepakat terhadap apa yang diputus.kan secara sukarela, tanpa ada paksaan dan tekanan. Dibuat dalam bentuk akta autentik atau bukan akta itu tidak ada ketentuan, yang penting masing-masing pihak mengetahui konsekuensi dari bentuk formal hasil perdamaian itu.

Konsekuensi dari bentuk formal itu berpenganuh pada kekuatan untuk pembuktian atau kekuatan pelaksanan putusan perdamaian tersebut manakala dikemudian hari timbul persoalan tentang putusan perdamaian. $\mathrm{Hal}$ ini berkaitan dengan bentuk surat sebagai alat bukti, sebab dalam hukum açaraiperdata mengatur perbedàan bentuk formal surat 
dalam pembuktian. Surat sebagai alat bukti dibedakan menjadi dua, yaitu surat yang merupakan akta dan surat-surat lain yang bukan akta. Sedangkan akta itu sendiri dibagi menjadi akta autentik dan akta di bawah tangan. ${ }^{23}$ Sedangkan dilihat dari segi mempunyai kekuatan pelaksanaan (eksekusi) perdamaian itu dibedakan menjadi perdamaian yang tidak mempunyai kekuatan memaksa dan yang mempunyai kekuatan memaksa.

Mengingat tujuan perdamaian itu adalah menyelesaikan sengketa dengan cepat dan biaya murah dan banyaknya ragam bentuk dari hasil suatu perdamaian, maka sebaiknya hasil perdamaian itu dibuat dan dirumuskan dalam bentuk autentik dan mempunyai kekuatan memaksa (eksekutoria). Untuk memenuhi kriteria tersebut tidak ada pilihan lain kecuali hasil perdamaian tahkim (perdamaian) yang dirumuskan itu dimintakan pengukuhan kepada hakim untuk menjadi keputusan pengadilan.

Mengapa hasil putusan tahkim harus dikukuhkan menjadi keputusan pengadilan, karena dalam hukum acara perdata hasil putusan perdemaian itu dikenal dengan dua istilah, yaitu damai di luar pengadilan dan damai di dalam sidang pengadilan. Damai di luar pengadilan itu artinya putusan perdamaian (tahkim) tidak dikukuhkan oleh hakim yang memeriksa perkaranya menjadi putusan pengadilan, dan para pihak harus sepakat untuk mengakhiri sengketa di pengadilan dengan cara mencabut perkara di pengadilan.

Kelemahan perdamaian di luar pengadilan manakala pihak yang berdamai itu tidak mematuhi putusan perdamaian (hakam) maka harus diperkarakan kembali ke pengadilan. Karena para pihak yang berdamai itu tidak wajib patuh, atas keputusan perdamaian, meskipun menurut pendapat Ahmad dan Abu Hanifah putusan yang diberikan oleh hakam (perdamaian) itu harus dijalani. ${ }^{24}$ Apabila ada pihak yang berdamai itu mempersoalkan atau bahkan tidak mau melaksanakan isi perdamaian itu maka pihak yang dirugikan akibat tidak dipatuhi putusan perdamaian yang disepakati yang dikenal dengan istilah wanprestasi, maka pihak yang tidak patuh (merugikan) tersebut harus diperkarakan kembali di pengadilan dengan pokok perkara yang berbeda dengan sebelumnya atau dengan istilah gugatan baru yaitu wanprestasi terhadap perdamaian.

Hal tersebut berbeda dengan pengertian damai di dalam pengadilan, yaitu hasil perdamaian yang disepakati itu dikukuhkan menjadi putusan hakim (acte van vergelijk), yang isinya menghukum kedua belah pihak untuk mematuhi isi perdamaian yang telah dibuat dan disepakati oleh mereka. ${ }^{25}$ Putusan perdamaian yang semacam itu bersifat final. Sebab putusan tersebut tidak dapat dilakukan upaya hukum dan apabila ada pihak yang tidak patuh terhadap putusan damai tersebut, maka pihak yang dirugikan akibat tidak dilaksanakannya isi putusan perdamaian tersebut dapat meminta bantuan pengadilan untuk memaksa pelaksanaan isi putusan perdamaian (eksekusi paksa).

Untuk mengantisipasi persoalan salah satu pihak yang tidak patuh atau tidak mau

${ }^{23}$ Sudikno Mertokusumo, Op.Cit,, hlm. 121

${ }^{24}$ T.M. Hasbi Ash-Shiddieqy, Op.Cit., hlm 72.

${ }^{25}$ Sudikno Mertokusumo, Op. Cit., hlm. 88, lihat juga Abdul Manan, Op. Cit., hlm. 99. 
melaksanakan isi putusan lembaga tahkim (perdamaian) maka putusan lembaga tahkim itu dimintakan pengukuhan untuk menjadi keputusan pengadilan. Untuk memenuhi. syarat agar keputusan lembaga tahkim itu dapat dikukuhkan oleh hakim pengadilan, maka sebelum lembaga tahkim mendamaikan, sengketa itu harus terlebih dahulu didaftarkan menjadi sengketa di pengadilan. Cara ini nampaknya yang lebih tepat, sebab dalam Pasal 2 ayat (1) Perma No. 2 Tahun 2003 ditentukan bahwa semua perkara perdata yang diajukan ke pengadilan tingkat pertama wajib untuk lebih dahulu diselesaikan meialuj perdamaian dengan bantuan mediator. Dalam sistem peradilan Islam mediator itu dikenal dengan istilah hakam.

Mengenai siapa yang ditunjuk sebagai mediatornya (hakamnya), sepenuhnya diserahkan kepada para pihak yang bersengketa di pengadilan tersebut. Sebagaimana ketentuan Pasal 4 ayat (1) Perma No. 2 Tahun 2003, bahwa para pihak dan atau kuasa hukum boleh memilih mediator dari daftar mediator yang dimiliki pengadilan atau mediator di luar daftar pengadilan. Sehingga bisa saja para pihak menunjuk orang atau lembaga lain yang dianggap kredibilitasnya diyakini mampu memberikan keadilan.

Hasil perdamaian yang dibuat dan disepakati oleh para pihak dengan mediator (hakam) itulah kemudian dimintakan pengukuhan hakim untuk menjadi putusan pengadilan. Sebagaimana ketentuan Pasal 11 ayat (5) Perma No. 2 Tahun 2003, bahwa hakim dapat mengukuhkan kesepakatan sebagai suatu akta perdamaian. Ketentuan Pasal 11 ayat (5) tersebut juga dapat difahami bahwa hasil perdamaian itu dapat dikukuhkan hakim yang memeriksa sebagai putusan pengadilan. Sehingga apabila dikemudian hàri ada pihak yang tidak patuh terhadap kesepakatan damai yang telah dibuat dan disetujui (wanprestasi) maka pihak yang dirugikan tinggal meminta bantuan pengadilan untuk memaksa pihak yang tidak patuh tersebut.

\section{Simpulan}

Berdasarkan uraian di atas dapat disimpulkan bahwa, penyelesaian perkara (sengketa) melalui prosedur perdamaian dalam sistem peradilan Islam diperbolehkan, bahkan apabila didasarkan pada sumber hukum Islam (al-Qur'an dan al-Hadits) penyelesaian perdamaian itu dianjurkan. Pola penyelesaian perdamaian tersebut dengan membentuk forum hakam atau melalui lembaga tahkim. Dalam perkembangan sejarah peradilan di Indonesia lembaga tahkim pernah dikembangkan para ulama (mubalig) dan raja-raja yang beragama Islam untuk mengisi kekosongan pengadilan yang belum di kenal pada masa itu yang mempunyai tujuan untuk melindungi hak-hak manusia dengan cara menegakkan keadilan.

Dalam agama Islam mentahkimkan atau menyelesaikan sengketa melalui damai (hakam) dibolehkan tidak dilarang, bahkan dianjurkan sesuai dengan surat an-Nisa' ayat (35) dan al-Hujarat ayat (9) sebatas yang didamaikan itu adalah menyangkut hak-hak manusia atau hak gabungan yang diberatkan (dominan) hak manusia. Sebab penyelesaian hak manusia itu tergantung manusia itu sendiri yang tidak dapat dipengaruhi oleh yang lain. Persoalan dibolehkannya bahkan dianjurkan menyelesaikan sengketa melalui jalur mediasi atau damai (islah) dalam Islam; karena menyelesaikan melalui jalur tersebut dapat mendamaikan manusia sehingga tidak 
berdampak adanya dendam (kusumat) di antara mereka. Sebab cara berdamai itu pendekatan yang digunakan tidak kalah menang tetapi win-win solution saling menerima dan saling memberi di antara pihak yang bersengketa.

Fungsi lembaga perdamaian (tahkim) adalah menyelesaikan sengketa yang dialami oleh manusia dengan cara damai (islah) yang didasarkan pada keadilan. Sehingga hakam atau muhakkam mempunyai tugas menyadarkan para pihak yang bersengketa untuk saling memberi dan menerima dengan metode winwin solution, sehingga proses penyelesaian sengketa menjadi cepat, sederhana dan biaya murah, karena prosedur yang ditempuh sederhana dan tidak birokratis.

Untuk memadukan agar putusan hakam sejalan dengan ketentuan Perma No. 2 Tahun 2003 dan hukum acara perdata (hukum positif), maka putusan perdamaian (hakam) dimohonkan untuk dikukuhkan oleh hakim sehingga menjadi putusan pengadilan. Hal ini penting apabila putusan damai (hakam) itu sudah menjadi putusan pengadilan apabila dikemudian hari ada yang tidak patuh, maka putusan damai tersebut tinggal dimintakan eksekusi paksa melalui pengadilan yang memutuskan. Hal ini menjadi efisien dan efektif.

\section{Daftar Pustaka}

Ahmad Azhar Basyir, Asas-Asas Hukum Muamalat, Ed Revisi, Yogyakarta, UII Press 2000

Abdul Manan, Penerapan Hukum Acara Perdata di Lingkungan Peradilan Agama, Cetakan Pertama, Jakarta, AlHikmah, 2000
Abd. Rahman Umar, Kedudukan Saksi dalam Peradilan Menurut Hukum Islam, Cetakan. 1, Jakarta, Pustaka Al-Husna, 1986

Cik Hasan Bisri, Peradilan Islam Dalam Tatanan Masyarakat Indonesia, Cetakan Pertama, Bandung, Remaja Rodakarya, 1997.

Daniel. S.Lev, Peradilan Agama Islam di Indonesia, Alih Bahasa Zaini Ahmad Noeh, Cetakan Kedua, Jakarta, Intermasa, 1986

Hadari Djenawi Taher, Pokok-Pokok Pikiran Dalam Undang Undang Peradilan Agama, Undang-Undang Peradilan Agama, Jakarta, Alda, 1989.

Mohammad Daud Ali, Hukum Islam Dan Peradilan Agama (Kumpulan Tulisan), Ed. 1, Cetakan 1, Jakarta, Raja Grafindo Persada, 1997.

Dan Habibah Daud, LembagaLembaga Islam Di Indonesia, Ed. 1. Cetakan 1, Jakarta, Raja Grafindo Persada, 1995

Muhammad Salam Madkur, Peradilan Dalam Islam, Alih bahasa Imran AM. Cetakan Keempat, Surabaya, Bina IImu, 1990 Sudikno Mertokusumo, Hukum Acara Perdata Di Indonesia, Edisi kelima Cetakan. Kedua, Yogyakarta, Liberty, 1999.

T.M. Hasbi Ash-shidieqy, Peradilan Dan Acara Islam, Bandung, al-Ma'arif. Tanpa tahun

Mahkamah Agung Republik Indonesia, "Peraturan Mahkamah Agung Republik Indonesia No. 2 tahun 2003 tentang Prosedur Mediasi di Pengadilan". 